\title{
Land Suitability Evaluation for Plantation Forest Development Based on Multi-criteria Approach
}

\author{
Aminuddin Mane Kandari ${ }^{1}$, Safril Kasim², Muh. Aswar Limi ${ }^{3}$, Jufri Karim ${ }^{4}$ \\ ${ }^{1}$ Spesifications Agroclimatology, Department of Environmental Science, Faculty of Forestry and Environmental Science, Halu Oleo University, \\ Southeast Sulawesi, Indonesia \\ ${ }^{2}$ Spesifications Agroforestry, Department of Environmental Science, Faculty of Forestry and Environmental Science, Halu Oleo University, \\ Southeast Sulawesi, Indonesia \\ ${ }^{3}$ Spesifications Management, Department of Agribusiness, Faculty of Agriculture, Halu Oleo University, Southeast Sulawesi, Indonesia \\ ${ }^{4}$ Spesifications GIS, Department of Geography, Faculty of Science and Mining Technology, Halu Oleo University, Southeast Sulawesi, \\ Indonesia
}

\section{Email address:}

manekandaria@yahoo.com (A. M. Kandari), safrilkasim1970@gmail.com (S. Kasim), aswar_agribusiness@yahoo.com (Muh. A. Limi), jufrikarim@yahoo.com (J. Karim)

\section{To cite this article:}

Aminuddin Mane Kandari, Safril Kasim, Muh. Aswar Limi, Jufri Karim. Land Suitability Evaluation for Plantation Forest Development Based on Multi-criteria Approach. Agriculture, Forestry and Fisheries. Vol. 4, No. 5, 2015, pp. 228-238. doi: 10.11648/j.aff.20150405.15

\begin{abstract}
Information of land suitability is needed to prioritize suitable forest plantation for land use development. This is important to increase land productivity and eficiency on forest management decision making process. This research aimed to: (1) to evaluate land suitability based on pedo-agroclimate characteristics for plantation forest development; (2) to identify the farming-based socio-cultural and economic characteristics; (3) to determine the priority level of trees that will be cultivated through plantation forest development. This research was conducted from January to May 2015 in four districts namely: Kapontori, Lasalimu, South Lasalimu, and Siotapina (KALALASSI region). These are located in Buton Island, Southeast Sulawesi Province, Indonesia. The research method used was a spatial research method using GIS [1]; [3]. The research has three main activities: data collection, evaluation, and mapping. Data collection included data on land biophysics, climate, and forest management development using survey method. Land evaluation was carried out on FAO method [14] and [15]. The major of trees were determined using LQ method [16] and the priority level of trees determine using MCDM method through the application of AHP [3];[4]. The last but not the least, spatial data development was used to map recommended forest land uses. The results showed that: (1) there were three major of trees in the research area, namely: Teak, Mahogany and Silk Tree; (2) based on land suitability classification, there are two classes found in the KALALASSI region, namely: moderately suitable (S2) which were located 3,836.05 ha for Teak and Mahagony, and Marginally Suitable (S3), which are located 3,343.45 ha for Teak, 3,467.20 ha for Mahagony, and 10,106.22 ha for Silk Tree; (3) the sequence of trees priority in KALALASSI region is Teak, Silk Tree, and Mahogany, then based on these recommendation, forest land uses and management plan were developed.
\end{abstract}

Keywords: Pedo-Agroclimate, Land Suitability, GIS, MCDM Method, Trees Priority, Forest Plantation, Development

\section{Introduction}

Forest is one of the natural resource that is important for human life. Trees provide many benefits in human life, especially for producing oxygen and absorbing carbon, thus making human beings can breathe well and remain comfortable living environment. Besides that, if properly managed, forest will provide economic benefits through job creation while maintaining environmental advantages. In the other words, the depletion of forest resource can lead to unavailability of oxygen and an increased in carbon concentration in the atmosphere, thus causing global warming, which in turn is definitely an uncomfortable environment even human life can be destroyed.

On the other hand, forest development sector encounters many obstacles and threats, including highly sensitive of forestry land use which can be rapidly change to other land uses, such as housing, infrastructure, and agriculture land, thus threatening a sustainability of forest community 
development [17]. Futhermore, according to [12] the conversion of forested land to other land uses will decrease the ecological benefits, such as hydrological roles, erosion control, reducing surface runoff and soil fertility control. Thus the need to continuously maintaining existing forest and the development of forest plantation efforts should be sustainably conducted in order to obtain socioeconomic and environmental benefits.

Buton regency is one of the potential areas in Southeast Sulawesi Province for the development of plantation forest because there is still many uncultivated dryland areas, especially in the KALALASSI region which includes the districts of Kapontori, Lasalimu, South Lasalimu and Siotapina. This region is dominated by dry land with an average yearly rainfall of $<2000 \mathrm{~mm}$. The development of plantation forest area in this region is potential. This is due to land availability and well adapted of trees to relatively low rainfall. To deal with a relative low rainfall in this area, the soil structure needed to properly managed so that infiltration capacity of soil can increase as well as soil aeration. [30] states that the trees growth are affected by soil structure. This is because the rough structure of soil has a better aeration and infiltration capacity compare to the clay soil.

According [25] the development of sustainable forest plantation area can be managed through corporate agribusiness system approach in overall management process ranging from commodities selection to production techniques (land preparation, planting, maintenance, harvesting and post-harvesting). [28] stated that there are at least five main aspects that must be met in order to achieve sustainable plantation of forest management, namely: (1) the rigidity and safety of forest resources, (2) the sustainability of production, (3) flora and fauna conservation aspect; and biodiversity as well as various line functions of the forest for the environment, (4) the economic benefits for the nation's development and community participation, (5) institutional aspect. Forestry plants can only be well grown and achieve optimal productivity when supported by land characteristics particularly suitable climatic and soil conditions. According to the [13], there are three aspects of climate that affect plant growth and productivity of the forest, namely changes of air temperature, changes of precipitation and atmospheric $\mathrm{CO}_{2}$ concentration. [29] states that the effective use of the land does not closely related to the climate change, however unappropriate land use can cause climate change.

According to [30] crop management will be more efficient and sustainable when in accordance with the biophysical and preferences of society toward plant species developed. [36] states that due to the differences in land capability, thus land use planning should be taken into account both biophysical suitability of the land, society preferency and economic impact through land cultivation.

Land use planning that involves multifactors and multicriterias, especially biophysical aspect based on pedo-agroclimate, and socio-economic and cultural aspects will be appropriate solution for land use development in the study area [2];[19]. However, a proper land use planning has not been developed due to lack of spatial and attribute data.

Based on aboved explanations, the need for conducting land suitability analysis for plantation forest management employing multi-criteria approach is urgent. This research aimed to: (1) to evaluate land suitability based on pedo-agroclimate characteristics for plantation forest development; (2) to identify the farming-based socio-cultural and economic characteristics; (3) to determine the priority level of trees that will be cultivated through plantation forest development.

\section{Study Area}

Buton regency is situated in the southeastern part of Sulawesi Island, Indonesia, and geographically located between $05^{\circ} 03$ '32" and $05^{\circ} 39^{\prime} 55^{\prime \prime}$ South Latitude and $122^{\circ} 40^{\prime} 44^{\prime \prime}$ and $123^{\circ} 13^{\prime} 26^{\prime \prime}$ East Longitude [6]. This research was conducted on four districts out of seven districts in Buton regency, including Kapontori $(38,450.00$ ha) [7], Lasalimu $(33,130.00$ ha) [8], South Lasalimu (17,090.00 ha) [9] and Siotapina $(24,760.00 \mathrm{ha})$ [10], which is abbreviated by the term KALALASSI region $(113,430.00 \mathrm{ha})$.

\section{Methodology}

This research using multiple criteria that include secondary data and primary data. Secondary data were collected from various sources that support the analysis and presentation of data / information area, both of which have shaped the basic data directly related to the biophysical aspects of land based pedo-agroclimate, as well as from the cultural and social aspects of farm-based economy, including demographics.

The research employs a spatial analysis method, using the ArcView GIS software. The research was conducted in three main: (1) survey, (2) evaluation, and (3) mapping.

These three main steps were performed in five stages: (a) preparation, (b) collection of total area and land biophysic data (physio-topography, climate, soil) and land use, (c) input and data analysis, (d) interpretation for land evaluation, and (e) development of land suitability map for forest plantation (f) determine of priority level of trees and mapping (Figure 1).

Figure 1 shows the schematic diagram of research activities. At the early stage, preparation was conducted to collect data and information on secondary and primary data. Secondary data were directly collected from the sources, while primary data were collected using survey method and interview, either directly or through questioners. Land biophysic data were directly collected in the field on each research site, based on technical guidelines provided by the Research Center for Soil and Agroclimate [32]; [31]; [27].

Method for soil sampling and analysis was based on Soil Survey Staff [33]; [34]; [35].

Similarly, social and economic data which has been collected and analyzed by appropriate method. Analysis of data to determine land suitability classes using FAO method [14] and [15]. The major of trees were determined using Location Quotient (LQ) method [16] and the priority level of 
trees determine using Multiple Criteria Decision Making (MCDM) method through the application of Analysis Hierarchy Process (AHP) [3];[4]. The last but not the least, spatial data development was used to map recommended forest plantation land uses.

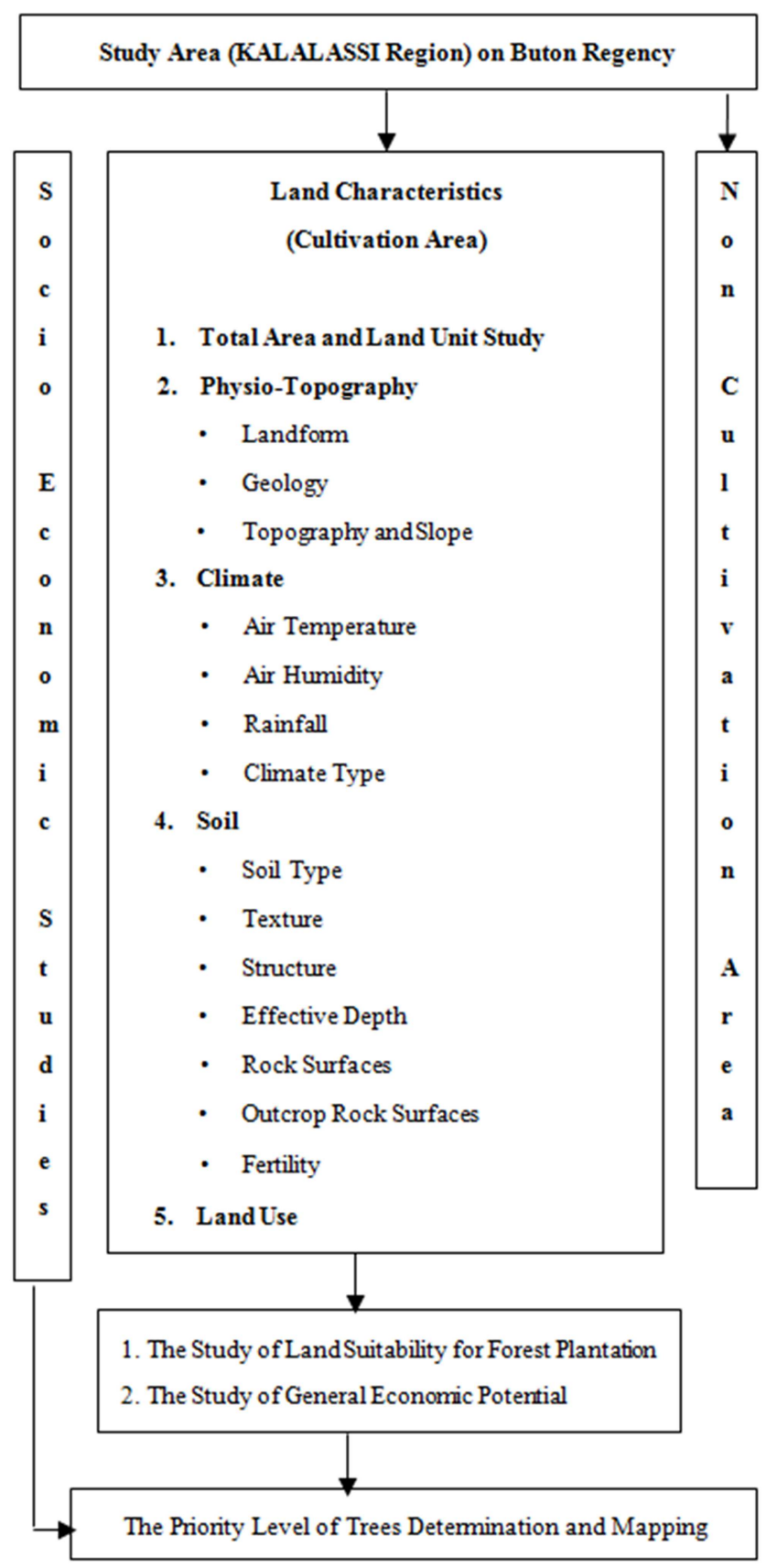

Figure 1. Diagram of Research Activity.

\section{Result and Discussion}

\subsection{Land Characteristics}

\subsubsection{Total Area and Land Unit Study}

Map interpretation, field observation and GIS analysis identify the total area of the study ((KALALASSI region) is $113,430.00$ ha. There is still $38.88 \%$ of the total area
(35,027.43 ha) can be developed as plantation with 214 land units, covering: Kapontori 73 units $(12,458.86$ ha or $35.57 \%)$, Lasalimu 65 units $(9,436.40$ ha or $26.94 \%)$, South Lasalimu 52 units $(8,709.84$ ha or $24.87 \%)$, and Siotapina 24 units $(4,422.33$ ha or $12.63 \%)$.

\subsubsection{Physio-Topography}

\section{(i). Landform}

GIS analysis interpretation and field observation show that there were five landform categories on the recerch region with a total area coverage is different, namely: Hill system $(\mathrm{H})$ 15,255.72 ha; Piedmont Land (P) 11,213.94 ha; Uplifted limestones (C) 4,965.02 ha; Marine Territory (B) 2,040.85 ha; and Aluvium Land (A) 1,551.89 ha. All categories are included in the four districts with different coverage areas, for example category hills system $(\mathrm{H})$ which has the highest coverage area was in Kapontori $(6,016.53 \mathrm{ha})$, and the lowest was in Siotapina (677.08 ha).

\section{(ii). Geology}

Interpretation of satellite images and regional geological map was relevant to the field observation of geological formation on research locations, in which the geological formation in the research region was relatively complex and they were grouped into nine formations: wapulaka (Wp) 13,452.31 ha; sampolakosa (Sm) 13,187.90 ha; tondo (Td) 4,461.36 ha; aluvium (Al) 2,358.81 ha; limestones (Bg) 727.49 ha; ultramafic kanpa (UbKp) 435.32 ha; winto (Wt) 225.43 ha; ultramafik (Uf) 166.26 ha; tobelo (Tb) 12.55 ha. Not all of these formations are in all research location, such as the formation Wt and Bg only in Lasalimu and Kapontori, $\mathrm{Tb}$ only in Siotapina, UbKp and Uf only in Kapontori. Geology formation that is located in four research location namely $\mathrm{Wp}$, $\mathrm{Td}$, and $\mathrm{Al}$, with an area of coverage vary from one location to others. Geological formation with the highest coverage area was Wp $(13,452.31$ ha or $38.41 \%)$, found in all research location with the highest area is in Kapontori (6.629.22 ha) and the lowest in Siotapina (695.85 ha).

\section{(iii). Topography and Slope}

The results showed that the topography in the research region are relatively varied, ranging from flat areas (flats), wavy (undulating), corrugated (rolling), rolling (hilly) to mountained (mountainous). The Slope ranges on the research region are varied that are grouped in to seven classed: $41-60 \%$ (12,974.82 ha); 9-15\% (6,755.97 ha); 16-25\% (5,573.40 ha), > $60 \%$ (5,069.29 ha), 2-8\% (2,972.42 ha); <2\% (1,671.13 ha), and $26-40 \%$ (10.41 ha). Slope range with the highest coverage area is $41-60 \%$, covering $12,974.82$ ha $(37.04 \%)$, and existed in all research locations, in which the highest coveraged area was in Kapontori (7,373.64 ha, and the lowest was in Siotapina (224.94 ha).

\subsubsection{Climate}

\section{(i). Temperature}

Climatic data analysis showed that the overall air temperature in the study area ranges from $26-280 \mathrm{C}$ to 
28.1-30oC, but the most widespread is the range of $28.1-30 \mathrm{oC}$ $(33,503.83$ ha or $95.65 \%)$, which cover broad areas of study, while the temperature range $26-280 \mathrm{C}$ is spread only in Kapontori with coverage $1,523.60$ ha $(4.35 \%)$.

\section{(ii). Humidity}

Climatic data analysis showed that the humidity in the study area consists of three categories, namely $83 \% ; 87 \%$, and $94 \%$, and which is humidity rate $87 \%$ dominated the research region $20,915.98(59.71 \%)$ and spread over to almost all of the research region. Humidity rate $83 \% 12,943.49$ (36.95\%) is only spread in Kapontori (11,290.90 ha) and in Lasalimu (1,652.59 ha).

\section{(iii). Rainfall}

There are four yearly rainfall categories over the research region, namely: $1,500-1,750 \mathrm{~mm}$ year-1. Rainfall 1,645.5 $\mathrm{mm}$ year-1 is dominated the research region $(21,188.19$ ha or $60.49 \%$ ). This is spread over in almost of the study area, except in Kapontori. Whereas rainfall with 1,552.4 mm year-1 is spread only in Kapuntori $12,315.64$ ha $(35.16 \%)$ and in Lasalimu (1,380.38 ha). Besides, there is also $1,747.2 \mathrm{~mm}$ year-1 only in Kapontori (1,523.60 ha).

\section{(iv). Climate Type}

Accumulation of all climate conditions, particularly monthly rainfall, creates a certain climate type. Based on Schmidth-Fergusson classification method in the research region, there are two types: $\mathrm{C}$ with a value of $\mathrm{Q}=55.22$ $(\mathrm{WMR}=6.7$ and DMR $=3.7$ ), which means a rather wet area with jungle vegetation, includes districts Kapontori. In addition, there is a climate type $\mathrm{D}$ with a value of $\mathrm{Q}=75.22$ ( $\mathrm{WMR}=5.7$ and DMR $=4.3$ ), which means the area is rather dry with forest vegetation season, covering districts Lasalimu, South Lasalimu, and Siotapina.

\subsubsection{Soil}

\section{(i). Soil Type}

The soil type ranges on the research region area varied, grouped into six classed: eutropepts 9,591.94 ha (27.38\%); tropudalfs $9,202.67$ ha $(26,27 \%)$; rendolls $8,713,00$ ha $(24.87 \%)$; tropudults $3,434.83$ ha $(9.81 \%)$; dystropepts $3,033.28$ ha $(8.66 \%)$; and hydraquents $1,051.72$ ha $(3.00 \%)$. The six types of soil are located in all research location, except in Kapontori. Tropudults and Dystropepts types are located in Siotapina. Eutropepts is the widest area and is located in Kapontori (5,617.69 ha), Lasalimu (1,642.60 ha), South Lasalimu (1,587.72 ha), and Siotapina (743.93 ha).

\section{(ii). Soil Texture}

The results showed that the soil texture in the research location consists of eight broad categories with different extent, namely: clay (L) 10,137.66 ha (28.94\%); sandy loam (SL) 6,951.01 ha (19.84\%); Sandy Clay Loam (SCL) 6,546.81 ha (18.69\%); Silty Clay (SiC) 3,955.07 ha (11.29\%); clay loam (CL) 3,917.04 ha (11.18\%); silty clay loam (SiCL) $1,777.03$ ha $(5.07 \%)$; loam sandy (LS) $1,642.12$ ha $(4.69 \%)$; and sandy clay (SC) 100.69 ha $(0.29 \%)$. The soil texture with the most extensive coverage is clay which spread over in the research location, which is 3,258.08 ha (Kapontori), 2,513.38 ha (Lasalimu), 2,307.87 ha (South Lasalimu), and 2,058.33 ha (Siotapina).

\section{(iii). Soil Structure}

The results showed that the soil structure in the area consists of three categories with a total area of coverage varies: blocky $21,341.79$ ha $(60.93 \%)$; granular $8,982.36$ ha $(25.64 \%)$, and crumb $4,703.28$ ha $(13.43 \%)$. The structure range with the highest coverage area is blocky and existed in all research locations, in which the highest coveraged area was in Kapontori (8,031.00 ha), South Lasalimu (6,090.64 ha), Lasalimu (5,329.41 ha), and the lowest in Siotapina (1,890.74 ha).

\section{(iv). Soil Depth}

Soil observation and measurement showed that the thickness of the solum and effective rooting depth in the research location consists of five categories with different scope: shallow (20 to $50 \mathrm{~cm}) 13,863.25$ ha $(39.58 \%)$; moderately deep ( $>50$ to $75 \mathrm{~cm}) 7,541.04$ ha $(21.53 \%)$; deep ( $>$ 75 to $100 \mathrm{~cm}) 6,005.93$ ha $(17.15 \%)$, very deep $(>100 \mathrm{~cm})$ $4,965.34$ ha $(14.15 \%)$, very shallow $(<20 \mathrm{~cm}) 2,661.88$ ha $(7.60 \%)$. Soil depth of the dominant category in the research region is Shallow (20 to $50 \mathrm{~cm}$ ), the widest available in Kapontori (5,536.94 ha), Lasalimu (4,394.33 ha), South Lasalimu (3,155.59 ha) and Siotapina (776.39 ha). While very deep soils are most widely available in South Lasalimu, Lasalimu, Kapontori and Siotapina which cover 2,123.00 ha, 1,327.38 ha, 808.02 ha and 696.94 ha respectively.

\section{(v). Rock Surface}

The results showed that the condition of the soil surface rocks in the study area consists of seven broad categories with different scope: very rocky (> 15-60\%) 9,313.07 ha (26.59\%); pretty rocky $(>3-15 \%) 7,385.79$ ha $(21.09 \%)$; a little rocky (0.01-0.1\%) 6,938.76 ha (19.81\%), a bit rocky (>0.1 to $3 \%)$ $4,774.70$ ha $(13.63 \%)$; very little rocky $(>50-90 \%) 3,352.13$ ha $(9.57 \%)$; rocky $(>90 \%) 1,942.64$ ha $(5.55 \%)$, and not rocky $1,320.33$ ha $(3.77 \%)$. The broadest category of surface rocks is very rocky, of which is located in Kapontori (4,563.03 ha), Lasalimu (2,069.39 ha), South Lasalimu (2,020.47 ha), and Siotapina (660.18 ha). While the not rocky is the smallest rocky surface which is relatively evenly distributed in all areas of study and covers 265.55 ha, 641.75 ha, 261.55 ha, 151.48 ha in Kapontori, Lasalimu, South Lasalimu and Siotapina respectively.

\section{(vi). Surface Rock Outcrops}

Land surface analysis showed that the condition of the ground surface rock outcrops in the study area consists of seven broad categories with different scope: pretty rocky $(>2$ to $25 \%$ ) $10,921.19$ ha $(31.18 \%)$; a little rocky (0.01 to $0.1 \%)$ $10,381.88$ ha $(29.64 \%)$; a bit rocky ( $>0.1$ to $2 \%) 4,773.72$ ha $(13.63 \%)$, very little rocky (> 50 to $90 \%) 3,389.44$ ha $(9.68 \%)$; very rocky ( $>25$ to $50 \%$ ) $3,159.00$ ha $(9.02 \%)$, not rocky $(0.00 \%) 1,320.33$ ha $(3.77 \%)$; and outcrop rock $(>90 \%)$ 
$1,081.88$ ha $(3.09 \%)$. The broadest category of surface rocks outcrops is pretty rocky, of which is located in Kapontori (4,883.87 ha), Lasalimu (2,816.99 ha), South Lasalimu (2,259.80 ha), and Siotapina (960.53 ha). While the outcrop rock is the smallest rocky outcrops surface which is relatively evenly distributed only in Siotapina (941.52 ha) and South Lasalimu (140.36 ha).

\section{(vii). Soil Fertility}

The results showed that the fertility of the soil in the research region consists of three broad categories with different scope: medium $26,205.85$ ha $(74.82 \%)$; high 8407.74 ha $(24.00 \%)$; and low 413.83 ha $(1.18 \%)$. From category soil fertility that is most widespread medium category, are the largest in Kapontori (9,018.85 ha), Lasalimu (6,651.56 ha), South Lasalimu (6,401.67 ha), and the smallest in Siotapina $(4,133.77 \mathrm{ha})$. While soil fertility with a low category, only in South Lasalimu (348.09 ha) and in Kapontori (65.74 ha).

\subsection{Land Use}

The interpretation result satellite data and field observation revealed that there are extremely diversed land primary forest (Htpr) 1,590.90 ha (4.54\%); mangrove (Mv) 826.66 ha
(2.36\%); agricultural wetlands (Ptlb) 608.66 ha bushes (ptlkcs) $14,660.90$ ha (41.86\%); secondary dry forest (htlksk) $6,453.86$ ha $(18,43 \%)$; bushes $(\mathrm{SmB}) 5,165.44$ ha uses over the research region, and they were classified in to ten categories, namely: dry land agriculture mixed with (14.75\%); dry land agriculture (Ptlk) 4,732.75 ha (13.51\%); (1.74\%); open land area (Lt) 449.86 ha (1.28\%); savana (Sv) 348.98 ha $(1.00 \%)$, and swamp bushes (Sbr) 189.22 ha $(0.54 \%)$. The widest land use is a mixture of dry land agriculture bushes, mostly located in Lasalimu (4,983.33 ha), while in South Lasalimu (4,925.59 ha), in Kapontori (2,425.89 ha), and in Siotapina (2,326.09 ha). Primary forest is only found in Kapontori (1,590.90 ha), shrub swamp only in Siotapina (189.22 ha), savana, open land area and field only in Kapontori and South Lasalimu.

\subsection{Land Suitability Potential for Plantation Forest}

There are three types of trees that has been evaluated using Land Suitability Classification for the plantation forest and management, namely Teak (Tectona grandis), Mahogany (Swietinia sp.) and Silk tree (Paraserianthes falcataria). Results of analysis of potential land suitability classification of the trees can be seen in Table 1.

Table 1. Result of Potential Land Suitability for Three Forest Trees Type in the KALALASSI Region on Buton Regency.

\begin{tabular}{|c|c|c|c|c|c|c|}
\hline \multirow[b]{2}{*}{ Forest Trees Type } & \multirow[b]{2}{*}{ Land Suitability Potential } & \multicolumn{5}{|c|}{ Size Coverage on Study Area (Ha) } \\
\hline & & $\begin{array}{l}\text { KA } \\
\text { (Kapontori) }\end{array}$ & LA (Lasalimu) & $\begin{array}{l}\text { LAS } \\
\text { (South Lasalimu) }\end{array}$ & $\begin{array}{l}\text { SI } \\
\text { (Siotapina) }\end{array}$ & $\begin{array}{l}\text { KALALASSI } \\
\text { Region }\end{array}$ \\
\hline \multirow{3}{*}{$\begin{array}{l}\text { Teak } \\
\text { (Tectona grandis) }\end{array}$} & S2 & 688.46 & $1,089.71$ & $1,363.80$ & 694.08 & $3,836.05$ \\
\hline & S3 & 165.58 & $1,377.80$ & $1,228.81$ & 571.26 & $3,343.45$ \\
\hline & $\mathrm{N}$ & $11,937.89$ & $7,176.91$ & $6,083.60$ & $3,442.88$ & $28,641.28$ \\
\hline \multirow{3}{*}{$\begin{array}{l}\text { Mahogany } \\
\text { (Swietinia sp.) }\end{array}$} & S2 & 688.46 & $1,089.71$ & $1,363.80$ & 694.08 & $3,836.05$ \\
\hline & S3 & 530.16 & $1,136.97$ & $1,228.81$ & 571.26 & $3,467.20$ \\
\hline & $\mathrm{N}$ & $11,573.31$ & $7,417.74$ & $6,083.60$ & $3,442.88$ & $28,517.53$ \\
\hline Silk Tree & S3 & $1,334.87$ & $2,693.66$ & $3,654.62$ & $2,423.07$ & $10,106.22$ \\
\hline $\begin{array}{l}\text { (Paraserianthes } \\
\text { falcataria) }\end{array}$ & $\mathrm{N}$ & $11,457.06$ & $6,950.76$ & $5,021.59$ & $2,285.15$ & $25,714.56$ \\
\hline
\end{tabular}

Source: GIS Analysis, 2015 Table 1 shows that the forest plantation of Teak, Mahogany and Silk Tree are principly feasible to be developed in the KALALASSI region of Buton Regency. Land suitability classes of those tree species are vary both between different trees at the same districts and similar trees in different districts.

\subsubsection{Teak}

Table 1 showed that the Teak has three classes of land Suitability, namely S2 class (Moderately Suitable), S3 class (Marginally Suitable), and N class (Permanently Not Suitable) with area of coverages vary both at the same districts and between one district to others. Potential land suitability of S2 class has a total coverage of 3,836.05 ha, which is the largest located in the District of South Lasalimu (1,363.80 ha) then folowed by Lasalimu District $(1,089.71 \mathrm{ha})$, while in two other districts have small different of area coverages (694.08 ha in Siotapina District and 688.46 ha in Kapontori). Permanently Not Suitable class (N) has a total area of coverage 2,8641.28 ha, which is the largest located in the district of Kapontori $(11,937.89 \mathrm{ha})$ and the smallest one is in Siotapina $(3,442.88$ ha). Map of the distribution of potential land suitability classes for Teak Plantation Forest in the KALALASSI region is presented in Figure 2.

\subsubsection{Mahogany}

Mahogany species has three potential land suitability, namely S2 (Moderately Suitable), S3 (Marginally Suitable), and N (Permanently Not Suitable) with an area of coverage varies, both the same trees at different districts and different trees at the same districts in the KALALASSI region (Table 1). Similarly with Teak species, the potential S2 class covers $3,836.05$ ha. The largest S2 class is located in the district of South Lasalimu (1,363.80 ha) and the smallest one is in the district of Kapontori (688.46 ha). However, the Permanently Not Suitable class covers a broad area of land (28,517.53 ha). The largest $\mathrm{N}$ class is located in the district of Kapontori $(11,573.33 \mathrm{ha})$ and the smallest one is in the district of 
Siotapina $(3,442.88 \mathrm{ha})$. The potential land suitability map for the Mahogany Plantation Forest in the KALALASSI region

presented in Figure 3.

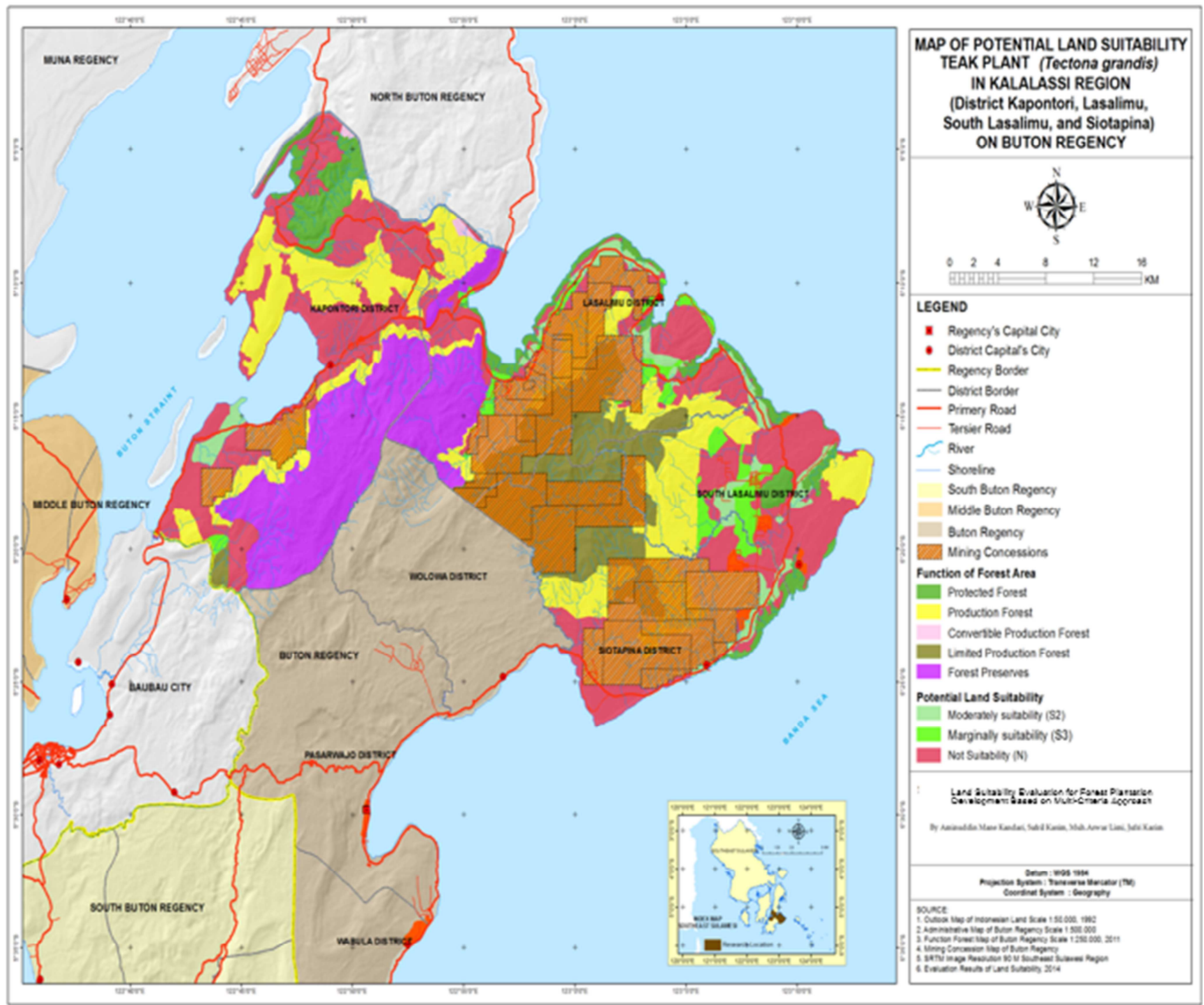

Figure 2. Map of Land Units and Land Suitability Potential for Teak Plantation in the KALASSI Region on Buton Regency.

\subsubsection{Silk Tree}

The potential land suitability for Silk Tree in KALALASSI region consists of only two classes, namely S3 (Marginally Suitable), and $N$ (Permanently Not Suitable). An area of coverages of potential land suitability of these two classes different, both at the same district and between one district to others in the KALALASSI region (Table 1). The total area coverage of potential land suitability for the S3 class Silk Tree is $10,106.22$ ha which is the largest located in South Lasalimu District $(3,654.62 \mathrm{ha})$ and the smallest one is in the Kapontori $(1,334.87$ ha). While the total area coverage of potential for $\mathrm{N}$ class is $25,714.56 \mathrm{ha}$, which is the largest is located in Kapontori District $(11,457.06 \mathrm{ha})$ and the smallest one is in the Siotapina (2,285.15 ha). The potential land suitability map of the development Silk Tree plantation in KALALASSI region presented in Figure 4.

\subsection{Determination of Trees Priority}

Trees priority in this study determined used AHP (Analytic Hierarchy Process) method based on multi-criteria approach, namely: (1) policy direction, (2) land suitability classes, (3) infrastructure, (4) location quotient (LQ), (5) farmer preferency, (6) market opportunities, and (7) (R/C ratio) of the three trees mentioned above (Teak, Mahogany, and Silk tree) in the KALALASSI region of Buton Regency. Results of the AHP analysis can be seen Figure 5.

Figure 5 shows that Teak Plantation has a first priority to be developed in the KALALASSI Region on Buton Regency. Based on AHP analysis, Teak has the highest weight of number of criteria in four districts, and obtain with weight of 2,76 in the district of Lasalimu and South Lasalimu, while the lowest weight of 2.48 achieved in the Siotapina District. The second priority in the KALALASSI region is Silk Tree which 
has second weight of number of criteria in four districts. Silk Tree achieves 2,42 as the highest weight in South Lasalimu District, and 2,21 as the lowest in Siotapina District. Whereas the third priority is Mahogany which has the weight number of criteria 2,23 as the highest in South

Lasalimu District, and 2,04 as the lowest in Siotapina District. The mapping of trees priority level in KALALASSI region on Buton Regency can be seen Figure 6.

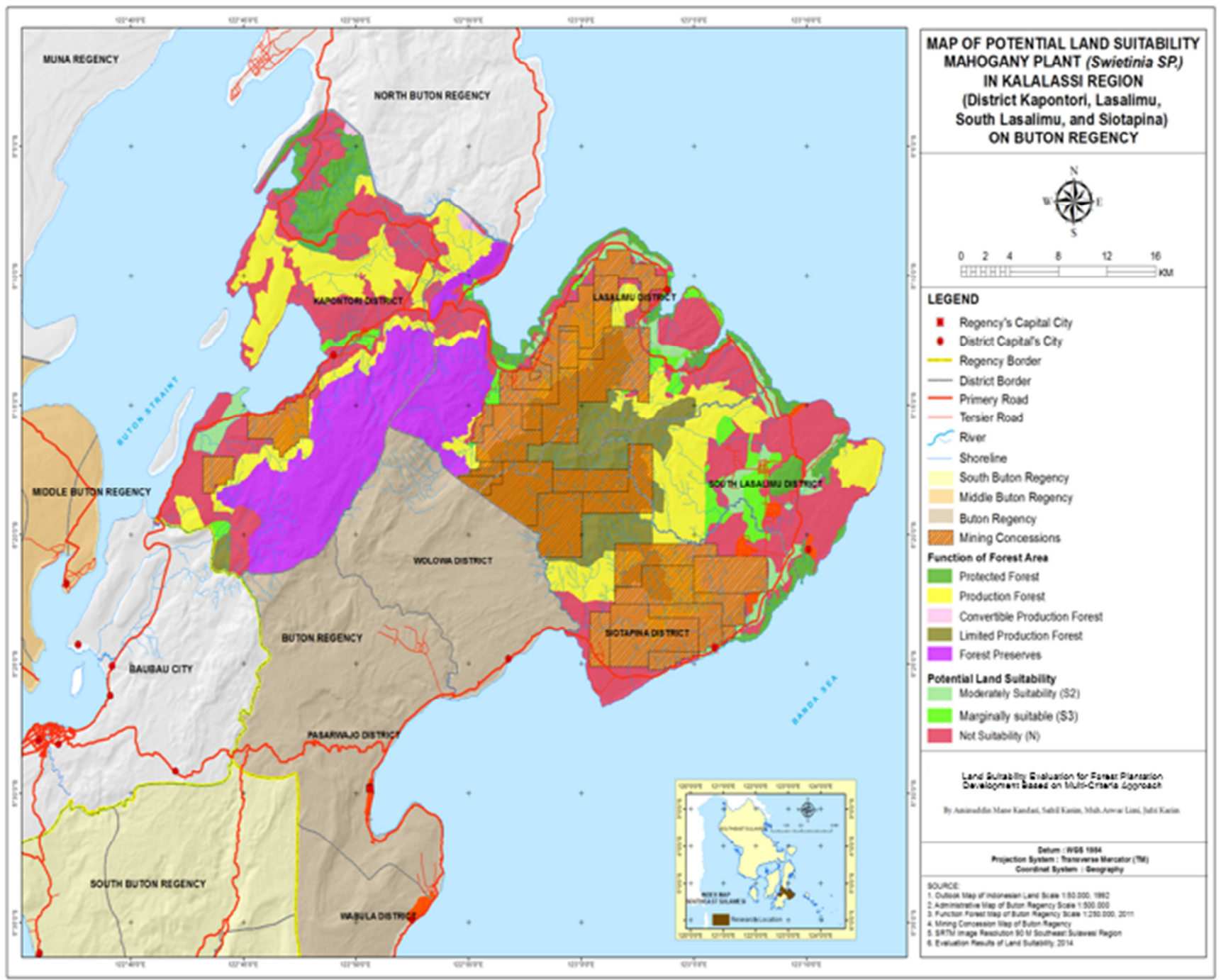

Figure 3. Map of Land Units and Land Suitability Potential for Mahogany Plantation in the KALASSI Region on Buton Regency.

\subsection{Discussion}

The results of land suitability classification for plantation forest depict that there is a wide opportunity to develop plantation forest in term of land availability and suitability in the KALALASSI region of Buton Regency, especially for the Teak, Mahogany and Silk Tree species. This is in line with the report [20] that local people of this region have cultivated these kinds of trees for generations. As mentioned aboved that Teak and Mahogany trees are moderately suitable (S2 class) to be cultivated in this region, which cover 3,836.05 ha. While the best suite for Silk Tree cultivation is S3 class (Marginally Suitable), which has total area of $10,106.22$ ha coverage. However, this research also found that there is a broad area of land that is permanently Not Suitable (N) for Forest Plantation, especially for Teak, Mahogany and Silk Tree species, which cover $25,000-29,000$ ha in each district. This can be related to the facts the land characteristics in the study area, especially dealing with effective depth of soil. It has been explained aboved that soil effective depthness in the region is dominated by the shallow category. Moreover, climatic conditions of the area belongs to $\mathrm{N}$ class become barrier factor of this piece of land. The $\mathrm{N}$ class are dominated by dry climate with average yearly rainfall of $<2000 \mathrm{~mm}$ and are included in climatic type C (rather wet) covering Kapontori district and climatic type D (slightly dry) covers Lasalimu, South Lasalimu and Siotapina districts. According [11] that climatic conditions can impact directly and indirectly on the plantation forest development.

The results also show that the productivity of these three species in four districts of the KALALASSI region is different. This fact is closely related to the suitability of the local climatic conditions with growing requirements needed by all these trees. This point of view is relevant to the statement [26] that components of natural climate factors become the main 
indicators to in plantation forest development. These are solar radiation, air temperature, evapotranspiration and precipitation. Moreover, the research also found that three species of trees in each district has different responds to the interaction between soil characteristics and climatic factors in the region. This fact is relevant to the explanation of [24] that the soil and climate factors, especially precipitation have significant roles to support plant growth process so as to achieve optimum growth and productivity must meet the requirements of soil and climate.

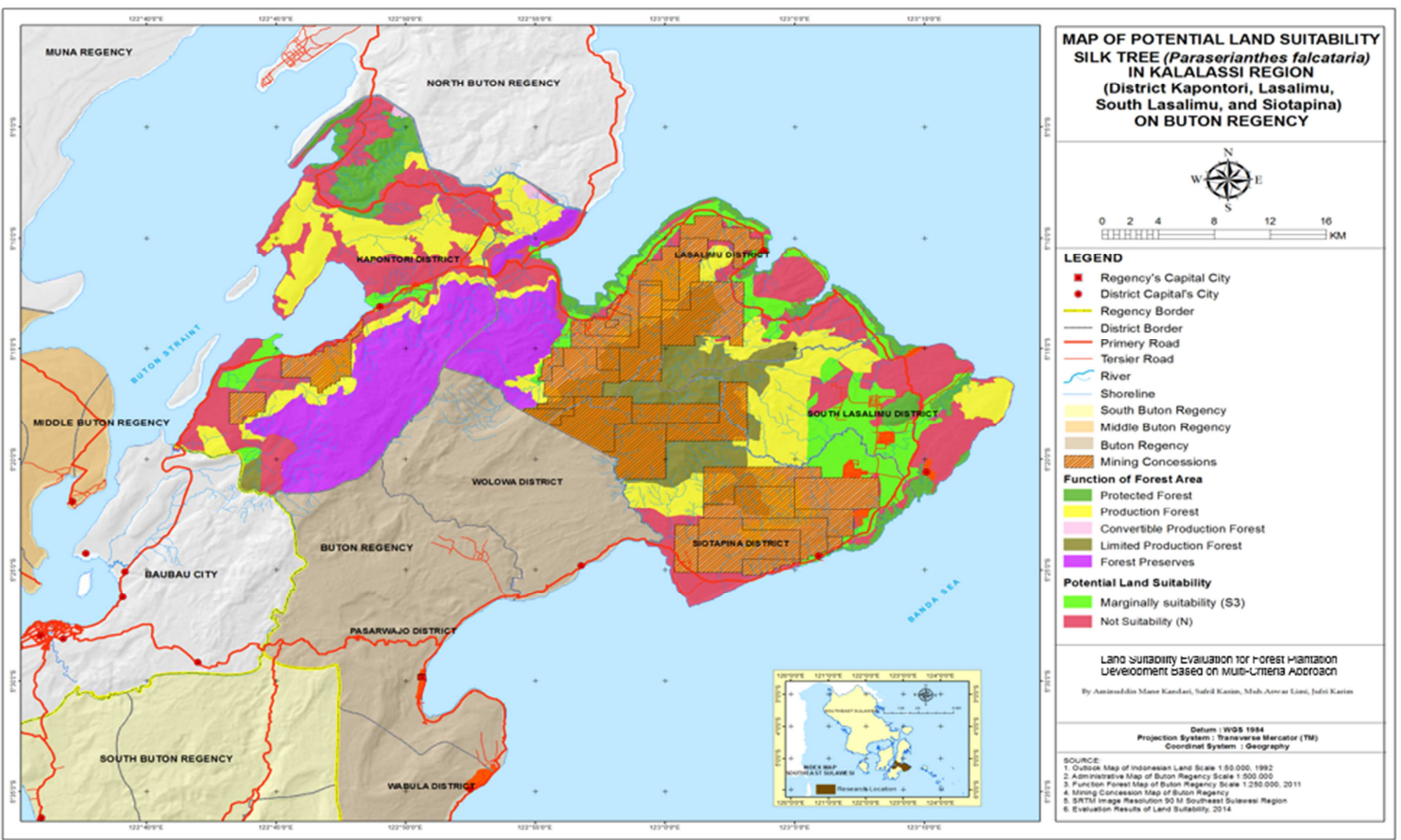

Figure 4. Map of Land Units for Land Suitability Potential for Silk Tree Plantation in the KALASSI Region on Buton Regency.

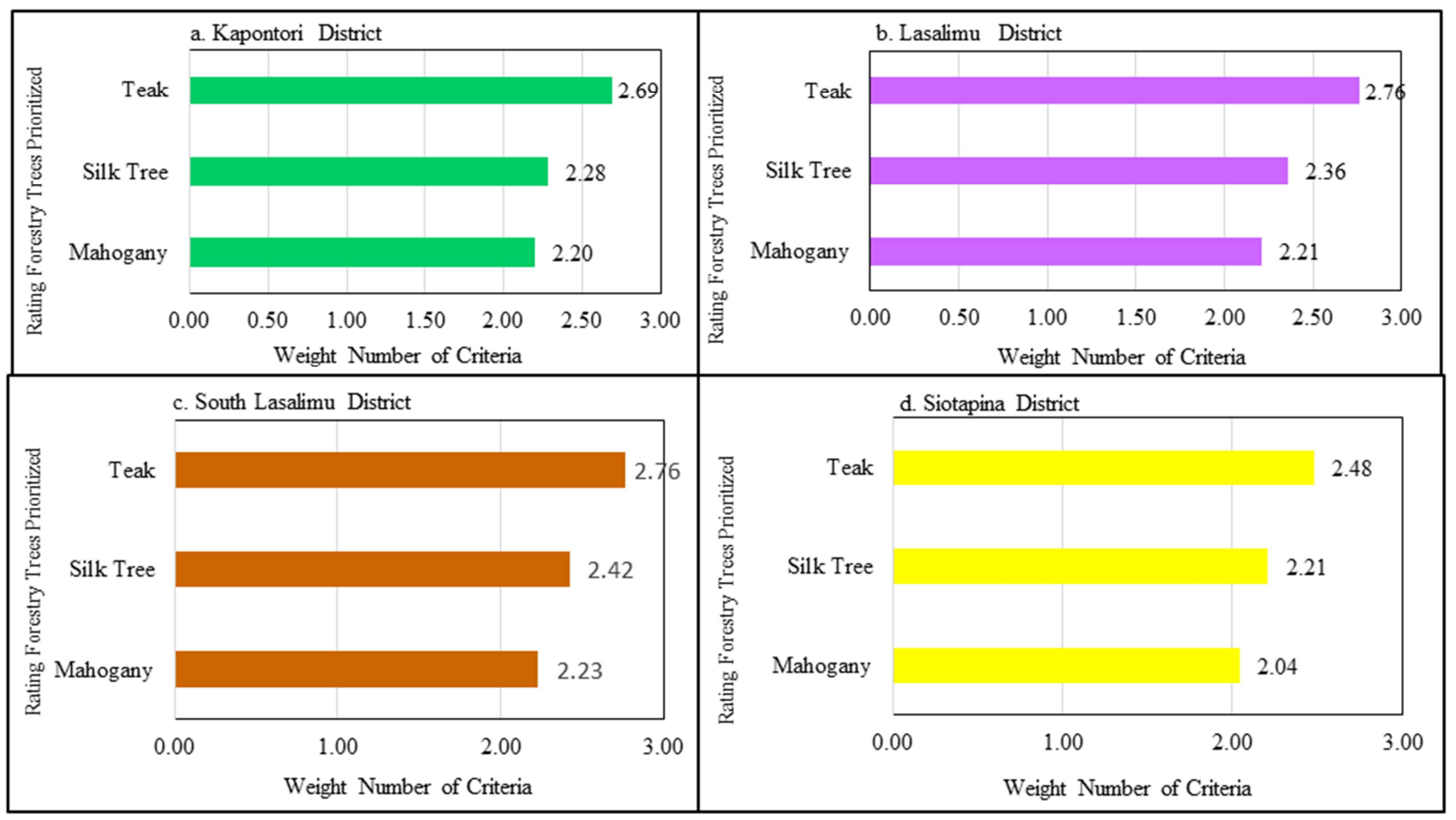

Figure 5. Diagram Result of Priority Trees Based on Multi-Criteria at: (a). Kapontori District; (b). Lasalimu District; (c). South Lasalimu District; (d). Siotapina District; in KALALASSI Region on Buton Regency. 


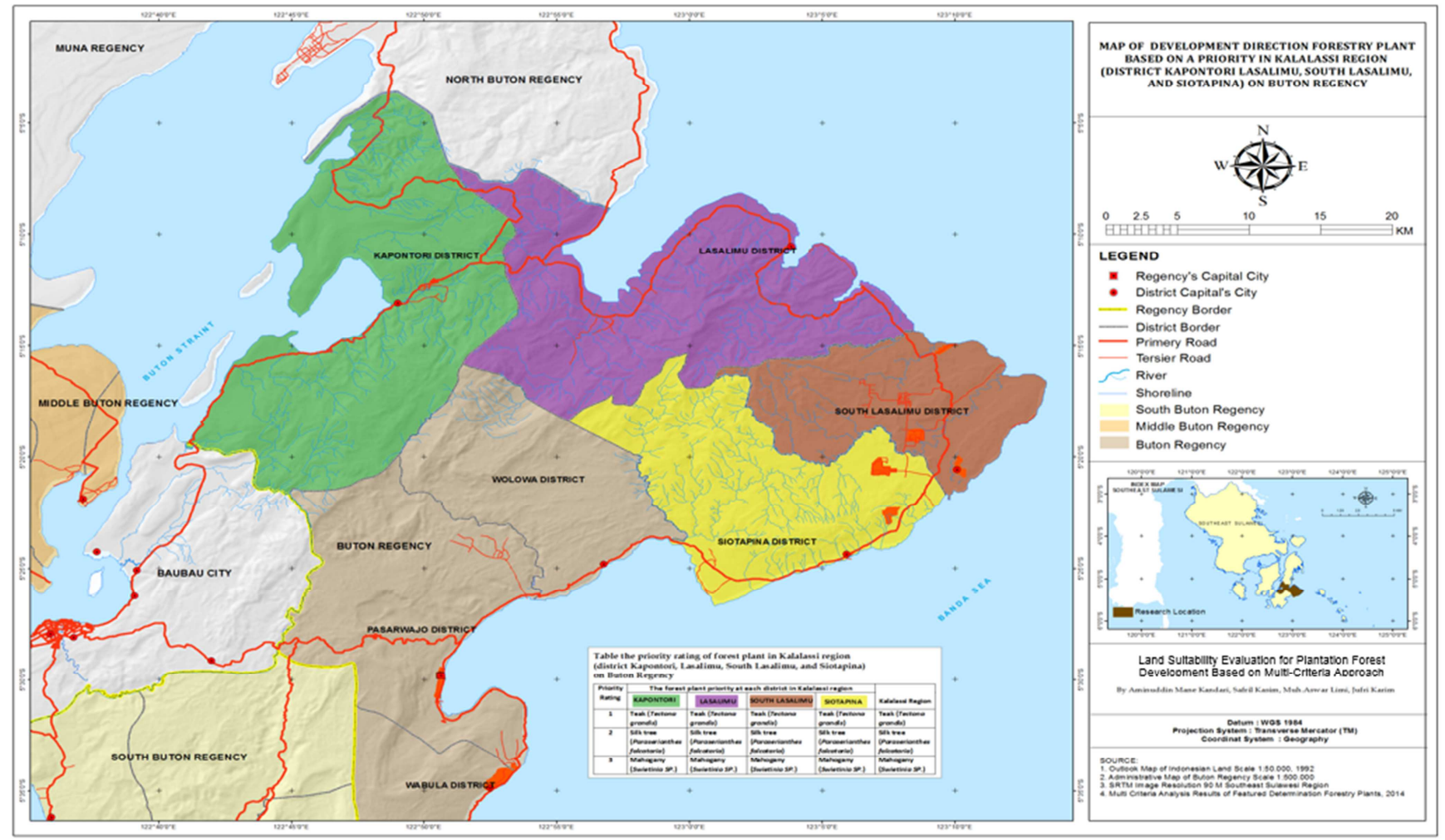

Figure 6. Map of Priority Level of Trees for Plantation Forest Development in the KALALASSI Region on Buton Regency.

A broad area of Not Suitable class of Teak, Mahogany and Silk Tree plantation development in the KALALASSI region can be caused by climate change and land use patterns. According [29] ineffective land use is closely related to climate change and can lead to a decrease in land productivity of the region. Therefore, land use management and development has primarily pay attention to the land use patterns so that negative impacts, especially in relation with climate change can be avoided. To this end, land suitability classification has a significant role in determining suitable plants match with soil and climatic characteristics.

Furthermore, the term of suitability is not only related to soil and climatic condition, but also it should be ecologically suitable for the surrounding environment and be economically viable and socially acceptable.

Effective depth of surface rock become one of the main limiting factors. It is therefore the need to solve this obstacle should be prioritized. This research found that rock surface with shallow effective depthness dominated land surface of the region, which is under this condition can minimize water holding capacity of the plan roots, then soil becomes more susceptible to the drought. Moreover, the fact that has been reported by [19], soil characteristics in the area of Buton Regency relatively have many limiting factors related to soil and climatic aspects, and it is therefore need solution-based approach.

This research also underlined that land resource analysis using spatial analysis method can efectively determine land use potency, then significantly support land use planning and development. In the case of conducting research, [5] states that using land use on research activities as a source of data can be integrated efficiently for planning and management through GIS approach. A GIS can effectively explore potential land resouces of the region which will further facilitate determination of the appropriate type of plants to be developed and planning and decision making process. This was also in line with the statement [18] and [3] that the spatial method by utilizing GIS can perfectly evaluate land characteristics so we can easily develop appropriate land use planning.

The results of multi-criteria analysis using AHP showed that Teak Plantation Forest is the first priority to be developed in the KALALASSI region. This is due to Teak is more suitable and well adapted to the climate and soil characteristics of the region. It is therefore Teak suitability class (S2 and S3 class) covers the largest area of the region, comparing to Silk Trees and Mahogany. Besides, Teak is economically more viable and socially more acceptable. This is relevant to statement [23] that Teak is a kind of trees that has a high grade and high economic value, and also high suitability to dry land so as to increase the income of farmers if proprely managed.

Silk Tree is the second priority due to total coverages of its land suitability class (S3). This relates to the ability of Silk Tree to adapt with various types of soil. According to [21] that Silk Tree can grow on various types of soil, does not requires fertile soil and can grow well in dry soils, alkaline soils and even in salty soil during drainage sufficient. Finally, Mahogany is the third priority in KALALASSI region. Based on land suitability classification, this kind of tree has S2 class but the total area of coverage smaller than Silk Tree and also has lower economic value than Silk Tree. According to [22], 
Mahogany can be well adapted with marginal condition of soil, but it has lower economic value compare with two Teak and Silk Tree. It is therefore, there are only a few local people have cultivated this species.

\section{Conclusions}

Based on the results of the research and discussion that has been described, it can be concluded as follows:

a. Land characteristics of KALALASSI Region on Buton Regency is dominated by dry land with marginal physiographic conditions, and various soil physical and chemical properties, and dry climate with an average yearly rainfall $<2000 \mathrm{~mm}$ and a climatic type belongs to C and D categories.

b. Plantation Forest of Teak, Silk Tree and Mahogany has a wide oppotunity to be developed in the KALALASSI region due to the suitability of soil, the availability of economic value and the acceptability of local farmers.

c. Forest Plantation Planning of Teak, Silk Tree and Mahogany if properly managed can bring about change of local farmers' prosperity through job creation and an increase of long term incomes.

\section{Acknowledgment}

First, the grateful thanks are delivering to the Head of Board Planning Agency of Buton Regency that has provided fund for the planning and implementation of the research activities. We also thank to the head of Forestry Department of Buton Regency who has allowed Team Research to access various data source from his office. A special thanks delivers to the head of Kapontori, Lasalimu, South Lasalimu, and Siotapina Districts as well as the government of all villages of KALALASI region both for their administerative and data supports. In particular thanks goes to The Rector of Halu Oleo University for his legal and moral supports in implementation and compliance of this research. Many thanks also go to the head of Soil Laboratory of Faculty of Agriculture, Hasanuddin University and the Head of GIS Laboratory of Faculty of Forestry and Environmental Science for their supports in soil analysis phase and map making activities process. Last but not the least, a very grateful thank goes to the research team for their dedication and time management so that this research can be accomplished on schedule.

\section{References}

[1] Baja, S. 2002. Aplikasi Sistem Informasi Geografi dan Analytic Hierarchy Process. Dalam Studi Alokasi dan Optimasi Penggunaan Lahan Pertanian. Warta Informatika Pertanian, Volume 11: 619-635.

[2] Baja, S. 2012a. Perencanaan Tata Guna Lahan dalam Pengembangan Wilayah. Pendekatan Spasial dan Aplikasinya. Penerbit ANDI, Yogyakarta. 378p.

[3] Baja, S. 2012b. Metode Analitik Evaluasi Sumber Daya Lahan:
Aplikasi GIS, Fuzzy Set, dan MCDM. Penerbit: IDENTITAS. Universitas Hasanuddin, Makassar. 242p.

[4] Baja, S. 2013. Modul Pelatihan Analytic Hierarchy Process (AHP)-Expert Choice untuk Pengembangan Komoditas Unggulan Wilayah (Procedure Guidelines).Disampaikan pada Pelatihan Analytic Hierarchy Proces (AHP) dalam Pengambilan Keputusan Spasial, Diselenggarakan oleh Pusat Penelitian dan Pengembangan Wilayah, Tata Ruang dan Informasi Spasial (WITARIS) Universitas Hasanuddin, Makassar, 11 Maret 2013.

[5] Bobade S. V., B. P. Bhaskar, M. S. Gaikwad, P. Raja, S. S. Gaikwad, S. G. Anantwar, S. V. Patil, S. R. Singh, dan A. K. Maji. 2010. A GIS-based land use suitability assessment in Seoni district, Madhya Pradesh, India. National Bureau of Soil Survey and Land Use Planning, Tropical Ecology 51(1): 41-54, 2010 ISSN 0564-3295, (C) International Society for Tropical Ecology, www.tropecol.com, Nagpur 440 010, India.

[6] [BPS Buton] Badan Pusat Statistik Kabupaten Buton. 2014. Kabupaten Buton Dalam Angka. Pasarwajo: BPS Kab. Buton, CV. Kainawa Molagina Bau-Bau.

[7] [BPS Buton] Badan Pusat Statistik Kabupaten Buton. 2014. Kecamatan Kapontori Dalam Angka. Pasarwajo: BPS Kabupaten Buton.

[8] [BPS Buton] Badan Pusat Statistik Kabupaten Buton. 2014. Kecamatan Lasalimu Dalam Angka. Pasarwajo: BPS Kabupaten Buton.

[9] [BPS Buton] Badan Pusat Statistik Kabupaten Buton. 2014. Kecamatan Lasalimu Selatan Dalam Angka. Pasarwajo: BPS Kabupaten Buton.

[10] [BPS Buton] Badan Pusat Statistik Kabupaten Buton. 2014. Kecamatan Siotapina Dalam Angka. Pasarwajo: BPS Kabupaten Buton.

[11] Broadmeadow, M., Ray, D., 2005. Climate change and British woodlands. Forestry Commission Information Note, $16 \mathrm{pp}$.

[12] Diniyati, D., E. Fauziyah, T.Sulistyawati, B. Achmad., A. Badrunasar, Suyarno, dan E. Mulyati. 2006. Kajian Sosial Ekonomi Budaya dan Jasa Hutan Lindung Di Suaka Margasatwa Gunung Sawal. Laporan Penelitian. Loka Litbang Hutan Moonson Ciamis. Tidak Dipublikasikan.

[13] EPA Home, 2013. Climate Impacts on Forest. United States Environmental Protection Agency. EPA Climate Science Research, Last update on 9 September 2013.

[14] [FAO] Food Agricultural Organization. 1976. A Framework for land evaluation. FAO Soils Bulletin No.32, Food and Agriculture Organisation of the United Nations, Rome.

[15] Hardjowigeno S dan Widiatmaka. 2007. Kesesuaian Lahan dan Perencanaan Tataguna Lahan. Gadjah Mada University Press. Yogyakarta. $352 \mathrm{p}$.

[16] Hendayana R. 2003. Aplikasi Metode Location Quotient (LQ) dalam Penentuan Komoditas Unggulan Nasional. Informatika Pertanian 12 (1): 658-675.

[17] Herawati, T. 2001. Pengembangan Sistem Pengambilan Keputusan dengan Kriteria Ganda dalam Penentuan Jenis Tanaman Hutan Rakyat. Contoh Kasus di Kabupaten Ciamis Jawa Barat. Thesis. Program Pascasarjana. IPB. Bogor. Tidak dipublikasikan. 
[18] Hezam M. Al., J. B. M. Akhir, S. A. Rahim, 2011. GIS-Based Sensitivity Analysis of Multi-Criteria Weights for Land Suitability Evaluation of Sorghum Crop in the Ibb Governorate, Republic of Yemen. J. Basic. Appl. Sci. Res., 1(9)1102-1111, 2011, TextRoad Publication, ISSN 2090-424X

[19] Kandari A. M. 2014. Optimasi Spatio-Temporal Lahan Pertanian di Wilayah Berpotensi Rawan Pangan. Disertasi. Tidak dipublikasi.

[20] Kasim S dan A.M. Kandari. 2015. Analisis Pengembangan Agroforestri di Kecamatan Lasalimu Kabupaten Buton. Majalah ECO GREEN. FHIL UHO ISSN: 2407 - 9049, Vol. 1, No: 1, April 2015. Hal. 55 - 64.

[21] Krisnawati, H., Varis, E., Kallio, M. and Kanninen, M. 2011a. Swietenia macrophylla King. ecology, silviculture and productivity. CIFOR, Bogor, Indonesia. (C) 2011 Center for International Forestry Research ISBN 978-602-8693-39-4.

[22] Krisnawati, H., Varis, E., Kallio, M. and Kanninen, M. 2011b. Paraserianthes falcataria (L.) Nielsen: ecology, silviculture and productivity. CIFOR, Bogor, Indonesia. (C) 2011 Center for International Forestry Research, ISBN 978-602-8693-41-7.

[23] Langenberger, G. and J. Liu, 2013. Performance of Smallholder Teak Plantations (Tectona Grandis) In Xishuangbanna, South-West China. Journal of Tropical Forest Science 25(3): 289-298 (2013).

[24] Lavalle, C., Micale F., Houston T. D., Camia A., Hiederer R., Lazar C., Conte C., Amatulli G., Genovese G. 2009. Climate change in Europe. Impact on agriculture and forestry. A. Review, Agron. Sustain. Dev. 29, 433-446.

[25] Mile, Y. M. 2007. Prinsip-Prinsip Dasar dalam Pemilihan Jenis, Pola Tanam dan Teknik Produksi Agribisnis Hutan Rakyat. Basic Principles on Species Choice and Production Techniques of Community Forestry Agribisnis INFO TEKNIS Vol. 5 no. 2, September 2007. Balai Besar Penelitian Bioteknologi dan Pemuliaan Tanaman Hutan. Balai Penelitian Hutan Ciamis.

[26] Mueller, L. U. Schindler, W. Mirschel., T. G. Shepherd, B. C. Ball., K. Helming., J. Rogasik, F. Eulenstein, H. Wiggering. 2010. Assesing the productivity functions of soils. A Review. Agron. Sustain. Dev. 30. 601-614. INRA.EDP. Sciences.
[27] Mulyani, A. 2001. Petunjuk teknis penyusunan peta pewilayahan komoditas pertanian berdasarkan zona agroekologi skala 1:50.000. Pusat Penelitian dan Pengembangan Tanah dan Agroklimat. Bogor.

[28] Nurtjahjawilasa, K. Duryat, I. Yasman, Y. Septiani, Lasmini, 2013. Konsep dan Kebijakan Pengelolaan Hutan Produksi Lestari dan Implementasinya (Sustainable Forest Management/Sfm). Modul. Natural Resources Development Center. Program Terestrial The Nature Conservancy Indonesia, November 2013, Jakarta.

[29] Rounselvell M. D. A., and D. S. Reay. 2009. Land use and climate change in UK. Land Use Policy 26S, S160-S169. Elsevier.

[30] Robert F. P. 2002. Effects of Soil Disturbance on the Fundamental, Sustainable Productivity of Managed Forests. USDA Forest Service Gen. Tech. Rep. PSW-GTR-183.

[31] Soekardi, M. 1993. Mengenal peta tanah. Pusat Penelitian Tanah dan Agroklimat. Bogor.

[32] Soekarman, 1993. Pengamatan tanah di lapang. Pusat Penelitian Tanah dan Agroklimat Bogor. Bogor.

[33] Soil Survey Division Staff, 1993. Soil survey manual. USDA Handbook No.18. United States Department of Agriculture, Washington DC.

[34] Soil Survey Laboratory Staff, 1991. Soil survey laboratory methods manual. SCS-USDA. October 1991; 611p.

[35] Soil Survey Staff. 2010. Keys to soil taxonomy. Eleventh Edition. United States Department of Agriculture, Natural Resources Conservation Service. Washington DC.

[36] Tabideh S. N. Hosseinzadeh, and K. R. Nezhad, 2014. Land Preparation: A Strategy for Sustainable Development: A Case Study In Dishmook Area Kuhkiloye City. Indian Journal of Fundamental and Applied Life Sciences ISSN: 2231- 6345 (Online) An Open Access, Online International Journal Available at www.cibtech. org /sp.ed/jls/2014/03/jls.htm. 2014 Vol. 4 (S3), pp. 1717-1728. 